\title{
Financial Well-Being among Public Employees in Malaysia: A Preliminary Study
}

\author{
N. Mokhtar ${ }^{1}$, A. R. Husniyah ${ }^{1}$, M. F. Sabri ${ }^{1} \&$ M. Abu Talib ${ }^{2}$ \\ ${ }^{1}$ Department of Resource Management and Consumer Studies, Faculty of Human Ecology, Universiti Putra \\ Malaysia, UPM Serdang, Selangor, Malaysia \\ ${ }^{2}$ Department of Human Development and Family Studies, Faculty of Human Ecology, Universiti Putra Malaysia, \\ UPM Serdang, Selangor, Malaysia \\ Correspondence: N. Mokhtar, Department of Resource Management and Consumer Studies, Faculty of Human \\ Ecology, Universiti Putra Malaysia, 43400 UPM Serdang, Selangor, Malaysia. E-mail: adib3074@gmail.com
}

\author{
Received: November 24, 2014 Accepted: March 26, 2015 Online Published: June 5, 2015 \\ doi:10.5539/ass.v11n18p49 \\ URL: http://dx.doi.org/10.5539/ass.v11n18p49
}

\begin{abstract}
Public employee's innovativeness, responsiveness, efficiency and friendliness in services are the core prescriptions to enhance the competitiveness of one's country. Financial well-being and employees are two aspects that consequently related with each other that have received substantial deliberation from researchers, employers and financial advisor. Financial well-being can affect both direct and indirectly towards an individual, team and also organization. Changes in employee's financial well-being level whether it becomes high or low will affect their job performance. The purpose of this study is to discuss the level of public employee's financial well-being in Malaysia as well as to examine the determinants of financial well-being. A total of 73 questionnaires have been distributed through e-survey (email based) using convenient sampling technique in order to conduct this pilot test (pre-test). Only 30 public employees have participated in this study. The results identified that majority of public employees is at the moderate level of financial well-being. Even so, appropriate action should be taken through financial education in order to prevent worst case scenario in the future.
\end{abstract}

Keywords: financial well-being, Malaysia, preliminary, public employee

\section{Introduction}

Financial well-being is one of the well-being elements besides career, physical, social and community (Rath \& Harter, 2010). The increasing level of standard of living, uncertain lifestyle habits, variety of commitments and fluctuation of stress level can impact not just towards individual financial well-being but also among employees generally. Employee's financial well-being displayed a significant relationship with employee's productivity (Zaimah, Masud, Haron, Othman, Awang, \& Sarmila, 2013). According to the Malaysia Insolvency Department (2010), bankruptcy cases for public employees in Malaysia in 2009 were 1086. Surprisingly in 2011, 3000 public employees were reported bankrupt (Lee \& Singh, 2013). Bankruptcy is one of the sign of economic ill being according to Xiao (2013). Thus, more analyses on employees' financial well-being are very crucial and need to be investigated.

Past literature demonstrated that issues with employees' financial well-being are influenced by determinants such as low level of financial literacy, poor financial management and stress towards their finances (Delafrooz \& Paim, 2011; Sabri \& Falahati, 2003). Consequently, these situations led to detrimental effect towards their daily life which lower their job productivity (Delafrooz, Paim, Sabri, \& Masud, 2010) and health (Kim, Garman, \& Sorhaindo, 2003; O’Neill, Sorhaindo, Prawitz, Kim, \& Garman, 2006).

Not long ago, statistics showed that individual financial issues correlated with overuse of credit card (Bronhier, 2014), high percentage of car loans (Habib, 2012) and high cost of medical expenses (Goh, 2013) have become the focal point in the mass media. As a result, debt, bankruptcy, low level of saving and inadequate money during their retirement stage (Blemin, 2013) was disclosed as the cause of financial problems.

Based on the causes of financial issues, this article aims to determine the level of public employee's financial well-being in Malaysia. Financial well-being level was measured by the subjective measurement. Subjective measurement of financial well-being can be beneficial in comprehension of an individual and family financial 
situation that able to provide response to individual and family towards their present-day and henceforward financial situation.

\section{Literature Review}

Financial well-being is an abstract concept being use to explain an individual or family financial situation. Initially, financial well-being is perceived as satisfaction or happiness towards financial situation (Kim, et al. 2003). Objective approach is known as quantitative approach that involved observation on financial situation that can be seen. Porter and Garman (1993) gave an example for the objective measure such as assets, consumptions goods, socioeconomic status and savings. Whereas, credit management, cash management, general management, retirement, estate planning and risk management were used to measure financial well-being subjectively.

Past studies studied socioeconomic characteristics such as age (Titus, Fanslow, \& Hira, 1989; Zaimah, 2011), level of education, marital status and income (Joo \& Grable, 2004; Baek \& DeVaney, 2004) have an impact on financial well-being. They found that those who are married, older, possess higher education level and high level of income showed a higher financial well-being.

Previous studies utilized diversity of approaches to evaluate financial well-being. Among of the approaches has been used is subjective measurement. According to Porter (1990), subjective measurement is value related qualitative indicators of financial situation. Based on O' Neill et al., (2006), subjective measurement might be accomplished via Incharge Financial Distress/Financial Well-Being (IFDFW) to measured financial distress or financial well-being for clients that undergo debt management program. Besides that, Personal Finance Employee Education Foundation utilized Personal Financial Wellness (PFW) scales in determines employees' financial health which enhances financial well-being through education (Prawitz \& Garman, 2008).

On the other hand, Falahati and Paim (2011) measured financial well-being among college students in Malaysia by adopting Lown and Ju's (1992) and Hira and Mugenda's (1999) six items instruments. Areas of financial concerns subjectively were asked regarding the amount of saving, financial management skills, recent financial situation, ability to meet wants, saving for emergency needs and affordability to spend.

However, O'Neill, et al., (2006) believed that subjective approach can prepare more complete understanding towards consumer finance behavior. This is because objective approach could not give out perceptual information of an individual financial situation (Porter \& Garman, 1993). Kim et al., (2003) explained that similar financial situation (based on objective approach) might be different in their perceptual financial well-being. In addition, subjective approach is closely related with ones perceived financial satisfaction.

\section{Method}

Respondents in this pre-test study were chosen conveniently from public sectors employees located in Selangor and Federal Territory of Putrajaya area. Based on Table 1, State of Selangor has been selected as the sampling frame because of the highest total population of public employees in Malaysia while Putrajaya was chosen because majority of the main government administration in Malaysia was located there. Moreover, Malaysia has the highest ratio of civil servants to population in the world (Faruqi, 2011) which makes public employees under the spotlight. Thus, public employees have become the targeted sample.

Table 1. Distribution of registered public employees according to the states in Malaysia for 2013

\begin{tabular}{cc}
\hline Serving States & Total \\
\hline Johor & 91,618 \\
Kedah & 71,867 \\
Kelantan & 70,238 \\
Melaka & 38,638 \\
Negeri Sembilan & 40,388 \\
Pahang & 65,437 \\
Pulau Pinang & 60,334 \\
Perak & 89,827 \\
Perlis & 15,313 \\
Selangor & 154,902 \\
Terengganu & 54,695 \\
Sabah & 92,396 \\
Sarawak & 90,599 \\
Federal Territory of Kuala Lumpur & 104,204 \\
Federal Territory of Labuan & 4,744 \\
\hline
\end{tabular}




\section{Source. EIS, HRMIS Database, September $13^{\text {th }} 2013$}

Financial well-being was measured by Malaysian Personal Financial Well Being Scale (MPFWBS) (Jariah, 2007) which comprised of 12 items that measure how satisfied an individual towards their financial well-being. It was modified according to the local context from the adaptation of InCharge Financial Distress/Financial Well-Being (IFDFW) by Prawitz, Garman, Sorhaindo, O'Neill, Kim and Drentea (2006). Within these 12 items, respondents were asked about control, attitude, behavior and confidence in their financial aspects.

\section{Results and Discussion}

From the overall sample, descriptive statistic revealed that respondents consist of 11 male and 19 female with the total of 30 respondents. Respondent's age ranged from 24 - 67 years old $(\mathrm{M}=34.7, \mathrm{SD}=13.7)$. Besides that, respondents background education level come with variety of categories such as secondary (SPM/MCE or $\mathrm{STPM} / \mathrm{HSC} / \mathrm{Certificate)}$ and tertiary (Diploma, Bachelor, Master or PhD) which represents 6.7 percent and 93.3 percent respectively. Most of the respondents are equally distributed among single and married/others respondents $(n=30)$. Respondents' average monthly income was RM3475 while majority of respondents acquired more asset value than debt with $73.3 \%$. The average working year experience among the respondents was 11 years. All this information can be summarized in Table 2.

Table 2. Profile of the respondents

\begin{tabular}{|c|c|c|}
\hline Demographic Characteristics & Frequency/Mean & Percentage/S.D. \\
\hline \multicolumn{3}{|l|}{ Gender } \\
\hline Female & 19 & 63.3 \\
\hline Male & 11 & 36.7 \\
\hline Age (years old) & 34.7 & 13.7 \\
\hline Less than 29 & 11 & 36.7 \\
\hline $30-35$ & 9 & 30.0 \\
\hline More than 35 & 10 & 33.3 \\
\hline \multicolumn{3}{|l|}{ Education Level } \\
\hline Secondary & 2 & 6.7 \\
\hline Tertiary & 28 & 93.3 \\
\hline \multicolumn{3}{|l|}{ Marital Status } \\
\hline Single & 15 & 50.0 \\
\hline Married/Others & 15 & 50.0 \\
\hline Income (RM) & 3475.0 & 2791.1 \\
\hline Less than 1500 & 14 & 46.7 \\
\hline $1600-4500$ & 6 & 20 \\
\hline More than 4500 & 10 & 33.3 \\
\hline \multicolumn{3}{|l|}{ Financial Status } \\
\hline Asset value less than outstanding debt & 3 & 10.0 \\
\hline Asset value equal to outstanding debt & 4 & 13.3 \\
\hline Asset value more than outstanding debt & 22 & 73.3 \\
\hline Working Experience (years) & 11.0 & 11.3 \\
\hline Less than 3 & 11 & 0.36 .7 \\
\hline $4-12$ & 10 & 0.33 \\
\hline More than 12 & 9 & 30 \\
\hline
\end{tabular}

Note. S.D.=Standard Deviation

The main objective for this study was to identify the respondents' level of financial well-being. Table 3 shows the mean score of financial well-being. Statement regarding troubling paying monthly bills indicates the highest mean which is 3.1. This reflect that respondents rarely struggling in paying bills. Similar with Zaimah (2011, 2012) findings reported that the highest mean score is found to be for the same statement. However, the two lowest mean score statements that give 2.2 mean score are how worried they are towards their current personal finances and their money sufficiency during retirement. Zaimah $(2011,2012)$ also stated identical results with her study. From this result, it demonstrates that respondents sometimes feel worried on their current personal finances as well as their money adequacy during old age. On the contrary, the composite score among public employees is 2.63. In general, respondents' financial well-being is at moderate level. 
Table 3. Financial well-being mean

\begin{tabular}{clc}
\hline Item & & Statement \\
\hline 1 & Your satisfaction level towards your overall financial situations. & 2.6 \\
2 & How worried are you about your personal finances today? & $\mathbf{2 . 2}$ \\
3 & How well off are you financially? & 2.7 \\
4 & Which of the following best describe your current financial situation? & 2.8 \\
5 & How do you feel about your current financial situation? & 2.6 \\
6 & How sure are you that you will have enough money to provide for a comfortable old age? & $\mathbf{2 . 2}$ \\
7 & How often does your last pay run out before the next pay day? & 2.8 \\
8 & How often do you have trouble paying monthly bills (electricity, telephone, installment, credit cards)? & $\mathbf{3 . 1}$ \\
9 & How confident are you that you have control over your personal finances? & 2.7 \\
10 & Your confidences are you that you know how to manage personal finances? & 2.7 \\
11 & How easy would it be for you to get money to pay a financial emergency that cost RM 1000? & 2.5 \\
12 & How worried are you about your personal finances in general? & 2.7 \\
\hline
\end{tabular}

Table 4 indicates the distribution of respondents' according to their financial well-being level. Financial well-being scores are divided into three levels consists of low (14 - 28), moderate (29 - 35) and high (36 - 48). Results disclosed 10 respondents (33.3\%) possessed mean score between 14 until 28. This has been classified as respondents having a low level of financial well-being. However, 11 respondents $(36.7 \%)$ acquired mean score of 29-35 which a moderate level of financial well-being. The remaining of the respondents ( 9 respondents, 30\%) with 36-48 means score as a high level of financial well-being.

Table 4. Respondent distribution according to financial well-being level

\begin{tabular}{cc}
\hline Financial Well Being Level & Frequency (\%) \\
\hline Low $(14-28)$ & $10(33.3)$ \\
Moderate $(29-35)$ & $11(36.7)$ \\
High $(36-48)$ & $9(30.0)$ \\
\hline
\end{tabular}

As shown in Table 5 is the comparison between socio-economic background and the level of respondents' financial well-being. Out of 30 respondents, 11 respondents have moderate level of financial well-being. Chi square test result $\left(\chi_{2}=4.093, \mathrm{df}=2, \mathrm{p}=.129\right)$ revealed that there is no significant difference between financial well-being level and gender. Thus, gender does not make a difference in determining ones financial well-being. Information on respondents' age also has homogeneous results as gender (11 respondents) at the moderate level. Furthermore, result of age also demonstrated no significant difference among the age groups towards their financial well-being. Tertiary level of education has majority of respondents with 90 percent which is why most of respondents faced a moderate level of financial well-being because they were able to utilize their financial capability to survive. However, chi square test stated there was no significant difference among secondary and tertiary level. Next, results divulged that for those who are single with less than RM1500 monthly income and acquired less than 3 years working experience has a moderate level of financial well-being. Even so, chi square discovered there was no significant difference in the respective groups.

Table 5. Respondent background according to financial well-being level

\begin{tabular}{ccccc}
\hline $\begin{array}{c}\text { Respondents' Profile } \\
\text { Gender }\end{array}$ & Low & $\begin{array}{c}\text { Financial well-being level } \\
\text { Moderate }\end{array}$ & High & Total \\
Male & $4(36.4)$ & $6(54.5)$ & $1(9.1)$ & $11(100.0)$ \\
Female & $6(31.6)$ & $5(26.3)$ & $8(42.1)$ & $19(100.0)$ \\
Age & $10(33.3)$ & $11(36.7)$ & $9(30.0)$ & $30(100.0)$ \\
Less than 29 & $3(37.5)$ & $5(62.5)$ & 0 & $8(100.0)$ \\
30 - 35 & $5(55.6)$ & $2(22.2)$ & $2(22.2)$ & $9(100.0)$ \\
More than 35 & $2(15.4)$ & $4(30.8)$ & $7(53.8)$ & $13(100.0)$ \\
Education Level & & & 0 & $3(100.0)$ \\
Secondary & 0 & $3(100.0)$ & $9(33.3)$ & $27(100.0)$ \\
Tertiary & $10(37.0)$ & & & $15(100.0)$ \\
Marital Status & $6(40.0)$ & $7(46.7)$ & $7(13.2)$ & $15(100.0)$ \\
Single & $4(26.7)$ & $4(26.7)$ & $9(30.0)$ & $30(100.0)$ \\
Married/Others & $10(33.3)$ & $11(36.7)$ & & \\
Monthly income (RM) & & & \\
\hline
\end{tabular}




\begin{tabular}{ccccc}
\hline Less than 1500 & $4(28.6)$ & $8(57.1)$ & $2(14.3)$ & $14(100.0)$ \\
$1600-4500$ & $5(41.7)$ & $2(16.6)$ & $5(41.7)$ & $12(100.0)$ \\
More than 4500 & $1(25.0)$ & $1(25.0)$ & $2(50.0)$ & $4(100.0)$ \\
Working Experience & $10(33.3)$ & $11(36.7)$ & $9(30.0)$ & $30(100.0)$ \\
(years) & $3(27.3)$ & $5(45.5)$ & $3(27.3)$ & $11(100.0)$ \\
Less than 3 & $5(50.0)$ & $3(30.0)$ & $2(20.0)$ & $10(100.0)$ \\
4 - 12 & $2(22.2)$ & $3(33.3)$ & $4(44.4)$ & $9(100.0)$ \\
More than 12 & &
\end{tabular}

The second objective for this study is to identify the determinants of socio-economic on financial well-being respondents. Unfortunately, result of multiple regression analysis exhibited that all 6 socio-economic predictors which are gender, age, education level, marital status, monthly income and working experience are not the predictors of financial well-being. In line with that, only 2.1 percent variance of financial well-being explained by these predictors. This proves that, other predictors than socio-economic has much more impact towards financial well-being. Besides that, a low number of respondents might be the reason for such result.

\section{Conclusion}

This paper has profiled the socio-economic and financial well-being level among public employees in Selangor and Federal Territory of Putrajaya. The analysis used shown qualitatively financial well-being of employees through subjective measurement. Multiple level of respondents' financial well-being consists of low, moderate and high level. As referred to the mentioned results, it seems that the saving cultures among public employees were still at the unsatisfactorily level and did not achieve the preference level. Furthermore, a lot of public employees did not nurture efficacious saving practices in their lives when they fall into bankruptcy and debts. They are found to be more inclined to spend more than what they earned.

A good saving practices, financial education, productive expenditure habit, determinants and mechanisms are examples that can elevate and inspire the influence of financial well-being should be studied and ascertained. More extensive attempt and involvement should be taken in cultivating employees through the equilibrium state of earnings and expenditure capacity. It is vital due to not just for this study but also past studies has authenticated financial well-being impact productivity of employees. It is recommended that employers might require to reduce their employee's financial problem and indirectly with decline financial stress at the same time in order to enhance employee's financial well-being. Financial education at the workplace such as financial knowledge can be advantageous for both employers and employees.

\section{Acknowledgements}

Appreciation to Research University Grant Scheme (RUGS), Universiti Putra Malaysia (UPM) in funding this research.

\section{References}

Baek, E., \& DeVaney, S. A. (2004). Assessing the baby boomers' financial wellness using financial ratios and a subjective measure. Family and Consumer Sciences Research Journal, 32, 421-348. http://dx.doi.org/10. 1177/1077727X04263826

Blemin, C. (2013, September 20). HSBC study: Faced with insufficient funds, Malaysians forced to semi retire. Retrieved from http://www.akpk.org.my/learning/articles-and-tips/id/1033/hsbc-study-faced-with-insuffic ient-funds-malays ians-forced-to-semi-retire

Bronhier, M. (2014, July 9). What you shouldn't do with your credit card. Retrieved from http://www.freemalay siatoday.com/category/money/2014/07/09/what-you-shouldnt-do-with-your-credit-car d/

Delafrooz, N., \& Paim, L. (2011). Determinants of financial wellness among Malaysia workers. African Journal of Business Management, 5(24), 10092-10100.

Delafrooz, N., Paim, L., Sabri, M. F., \& Masud, J. (2010). Effect of financial wellness on the relationship between financial problem and workplace productivity. World Applied Sciences Journal, 10(8), 871-878.

Falahati, L., \& Paim, L. (2011). Gender differences in financial well being among college students. Australian Journal of Basic and Applied Sciences, 5(9), 1765-1776.

Faruqi, S. S. (2011). Safeguards for public servants. In Malaysia world's No. 1 highest civil servants-to-population ratio! Its tenure of service legally vulnerable but notoriously difficult to dismiss! Retrieved from http://rightways.wordpress.com/2011/10/19/public-servants-legally-vulnerable-but-notoriou sly-difficult-against-the-delinguents/ 
Goh, L. (2013, March 24). Investing in medical insurance. Retrieved from http://www.akpk.org.my/learning/ articles-and-tips/id/886/investing-in-medical-insurance

Habib, S. (2012, December 9). A second chance for bankrupt. Retrieved from http://www.thestar.com.my/ story/?file $=/ 2012 / 12 / 9 /$ nation $/ 12434811 \&$ sec $=$ nation

Hira, T. K., \& Mugenda, O. M. (1999). The relationships between self-worth and financial beliefs, behaviour, and satisfaction. Journal of Family and Consumer Sciences Education, 91(4), 76-82.

Joo, S., \& Grable, J. E. (2004). An exploratory framework of the determinants of financial satisfaction. Journal of Family and Issues, 25(1), 25-50. http://dx.doi.org/10.1023/B:JEEI.0000016722.37994.9f

Kim, J., Garman, E. T., \& Sorhaindo, B. (2003). Relationships among credit counselling clients' financial well-being, financial behaviours, Financial Stressor Events, and Health. Financial Counselling and Planning Education, 14(2), 75-87.

Lee, S., \& Singh, R. (2013, August 2). At the tip of the tentacle-3000 civil servants bankrupt in just one year. Retrieved from http://www.themalaysianinsider.com/malaysia/article/at-the-tip-of-the-tentacle-3000-civilservants-bankrupted-in-just-1-year

Lown, J., \& Ju, I. (1992). A model of credit use and financial satisfaction. Financial Counselling and Planning, 3, 105-124.

O’Neill, B., Sorhaindo, B., Prawitz, A. D., Kim, J., \& Garman, E. T. (2006). Financial distress:Definition, effects, and measurement. Consumer Interest Annual, 52, 1-8.

Porter, N. M. (1990). Testing a model of financial well-being. Blacksburg: Virginia Polytechnic Institute and State University.

Porter, N. M., \& Garman, E. T. (1993). Testing a conceptual model of financial well-being. Financial Counselling and Planning, 4, 135-164.

Prawitz, A. D., Garman, E. T., Sorhaindo, B., O’Neill, B., Kim, J., \& Drentea, P. (2006). InCharge financial distress/financial well-being scale: development, administration, and score interpretation. Financial Counselling and Planning, 17(1), 34-50.

Rath, \& Harter. (2010). The Economics of Well Being. In Well Being: The Five Essential Elements. Retrieved from http://www.wbfinder.com/content/File/.../The_Economics_of_Wellbeing.pdf

Sabri, M. F., \& Falahati, L. (2003). Predictors of financial well being among Malaysian employee: Examining the mediate effect of financial stress. Journal of Emerging Economies and Islamic Research, 1(3), 1-16.

Titus, P. M., Fanslow, A. M., \& Hira, T. K. (1989). Net worth and financial satisfaction as a function of household money manager's competencies. Home Economics Research Journal, 17(6), 309-317. http://dx.doi.org/10.1177/1077727X8901700404

Xiao, J. J. (2013). Family economic well-being. In G. W. Peterson, \& K. R. Bush (Eds.), Handbook of Marriage and the Family (pp. 573-610). New York: Springer.

Zaimah, R. (2011). Pengaruh pengetahuan, tingkahlaku dan pembuatan keputusan kewangan ke atas kesejahteraan kewangan pekerja sektor awam yang berkahwin (Unpublished doctoral dissertation), Universiti Putra Malaysia, Serdang.

Zaimah, R., \& Md Sum, S. (Eds.). (2012). Prosiding daripada Persidangan Kebangsaan Ekonomi Malaysia: Transformasi Ekonomi dan Sosial Ke Arah Negara Maju. Ipoh, Perak.

Zaimah, R., Masud, J., Haron,S. A., Othman, M., Awang, A. H., \& Sarmila, M. D. (2013). Financial well-being: Financial ratio analysis of married public sector workers in Malaysia. Asian Social Science, 9(14), 1-6. http://dx.doi.org/10.5539/ass.v9n14p1

\section{Copyrights}

Copyright for this article is retained by the author(s), with first publication rights granted to the journal.

This is an open-access article distributed under the terms and conditions of the Creative Commons Attribution license (http://creativecommons.org/licenses/by/3.0/). 